\title{
Dissent in Consensusland: An Agonistic Problematization of Multi-stakeholder Governance
}

\author{
Martin Fougère ${ }^{1}\left[\right.$ Nikodemus Solitander $^{2}$
}

Received: 4 June 2018 / Accepted: 13 December 2019 / Published online: 23 December 2019

(c) The Author(s) 2019

\begin{abstract}
Multi-stakeholder initiatives involve actors from several spheres of society (market, civil society and state) in collaborative arrangements to reach objectives typically related to sustainable development. In political CSR literature, these arrangements have been framed as improvements to transnational governance and as being somehow democratic. We draw on Mouffe's works on agonistic pluralism to problematize the notion that consensus-led multi-stakeholder initiatives bring more democratic control on corporate power. We examine two initiatives which address two very different issue areas: the Roundtable on Sustainable Palm Oil (RSPO) and the Bangladesh Accord on Fire and Building Safety (The Accord). We map the different kinds of adversarial relations involved in connection with the issues meant to be governed by the two initiatives, and find those adversarial relations to take six main shapes, affecting the initiatives in different ways: (1) competing regulatory initiatives; (2) pressure-response relations within multi-stakeholder initiatives; (3) pressure-response relations between NGOs and states through multi-stakeholder initiatives; (4) collaboration and competition between multi-stakeholder initiatives and states; (5) pressure-response relations between civil society actors and multi-stakeholder initiatives; and (6) counter-hegemonic movements against multi-stakeholder initiatives as hegemonic projects. We conclude that multi-stakeholder initiatives cannot be democratic by themselves, and we argue that business and society researchers should not look at democracy or politics only internally to these initiatives, but rather study how issue areas are regulated through interactions between a variety of actors — both within and without the multi-stakeholder initiatives—who get to have a legitimate voice in this regulation.
\end{abstract}

Keywords Agonistic pluralism · Democracy $\cdot$ Multi-stakeholder initiatives (MSIs)

\section{Introduction}

The contemporary primacy of addressing sustainable development challenges has led to a seemingly universal acceptance of the 'partnership paradigm', whereby actors from several spheres of society (market, civil society and state) form collaborative arrangements to reach sustainability objectives (Glasbergen 2007; Seitanidi 2010). This trend, discussed under various umbrella terms such as 'transnational private

Martin Fougère

fougere@ hanken.fi

Nikodemus Solitander

solitander@hanken.fi

1 Hanken School of Economics, Management and Organization, Arkadiankatu 22, 00100 Helsinki, Finland

2 Hanken School of Economics, Supply Chain Management and Social Responsibility, Arkadiankatu 22, 00100 Helsinki, Finland regulation' (Bartley 2007), 'private governance' (Mayer and Gereffi 2010), or 'multi-stakeholderism' (Raymond and DeNardis 2015), has recently been further institutionalized through UN Sustainable Development Goal 17, which presents 'multi-stakeholder partnerships' as a panacea for sustainability issues (see United Nations 2015). While few would disagree that collaborative approaches are desirable in order to address the complex problems at hand, it has been noted that within partnerships for sustainable development, "potential partners will only collaborate structurally if each of them is convinced it stands to gain from the partnership" (Glasbergen 2011, p. 6). Thus, for partnerships to work, there needs to be an alignment between the interests of each party and the overall objective of the partnership. In this context, dissent is often portrayed as a perversion and success as something that is non-conflicting, in line with business-driven Corporate Social Responsibility (CSR) discourse (Blowfield 2005; Banerjee 2008; Fougère and Solitander 2009). 
Presented as a challenge to understanding CSR only in terms of a business case, seminal works on political CSR (Scherer and Palazzo 2007, 2011) have theorized corporations as 'political actors', and argued that corporations take on a political role when they engage in the transnational governance of issues that nation states are not able to regulate. The empirical phenomenon most in focus in political CSR has been multi-stakeholder initiatives involving business actors, civil society organizations and sometimes staterelated actors. Habermasian deliberative democracy has been used as a lens to not only frame this empirical phenomenon, but also legitimize these arrangements as improvements to transnational governance. The argument is that these arrangements, which are presented as pragmatically involving in the governance of certain issues the important stakeholders, are in some way democratic because different interests are allegedly represented and consensus is meant to be reached through deliberation.

This argument has given birth to a lively academic debate centred around political CSR (see e.g. Frynas and Stephens 2015; Scherer et al. 2014, 2016) and on multi-stakeholder initiatives (see e.g. Cheyns and Riisgaard 2014). A variety of critiques engaging specifically with Scherer and Palazzo's works have been articulated (e.g. Banerjee 2018; Baur and Arenas 2014; Dawkins 2015; Edward and Willmott 2013; Mäkinen and Kourula 2012; Moog et al. 2015; Whelan 2012), on both empirical and theoretical grounds. Partly as a response to these critiques, Scherer et al. (2016) have suggested a reframing of political CSR into a political CSR 2.0 which would bring the role of the state back in and which would perhaps be more open to more radical conceptualizations, such as neo-Gramscian (e.g. Levy et al. 2016) and decolonial (e.g. Ehrnström-Fuentes 2016) perspectives. But our contention is that more critique is needed of the larger underlying 'post-political' and 'post-democratic' turns (e.g. Swyngedouw 2005; Blühdorn 2013; Brown and Tregidga 2017 ) inscribed in consensus-driven theories of collaborative governance. In many ways, multi-stakeholder initiatives can be seen as post-politics, i.e. "the art of suppressing the political" (Rancière 2007, p. 11), wherein democracy and governance are reconceived as consensual dialogue in a neutral terrain and with 'technical', incremental solutions that supposedly benefit everyone (Brown and Tregidga 2017). These post-political forms of regulation (Mouffe 2005; Garsten and Jacobsson 2013) typically have depoliticizing tendencies, which need to be counteracted through various expressions of dissent (Swyngedouw 2011).

In this paper, we draw on Mouffe's (2005[1993], 1999, $2000,2005,2013$ ) works on agonistic pluralism, often framed as a critique of Habermasian deliberative democracy, to further problematize the notion that consensus-led multi-stakeholder initiatives bring more democratic control on corporate power. These initiatives are often framed in terms of consensus, through processes of reasoned accordance between corporations and civil society and other stakeholders (Whelan 2013). But as Mouffe (1999, p. 756) argues, "every consensus exists as a temporary result of a provisional hegemony, as a stabilization of power and that always entails some form of exclusion". Thus, to bring back the political in the political CSR debate, it is important to not only look at the actors that are included in multi-stakeholder initiatives and that 'happily' contribute to the provisional hegemony it seeks to set up, but also at those actors that for different reasons are excluded from the initiatives or have chosen to act as adversaries from within or outside them. Framing multi-stakeholder initiatives through agonistic pluralism questions the notion of deliberative democracy by inserting issues of power asymmetries and conflict (Whelan 2013; Dawkins 2015). Such framing also makes it possible to see civil society engagement in these initiatives as more than just a matter of co-optation of civil society organizations by corporate interests (Whelan 2013; Burchell and Cook 2013).

This paper also answers the call of Whelan (2013) for more empirical studies on identifying and analysing cases of 'dissensual CSR' characterized by adversarial relations rather than by consensus. In order to study these eminently political dynamics, we discuss the cases of two very different multi-stakeholder initiatives, each with specific agonistic patterns: (1) the Roundtable on Sustainable Palm Oil (which we refer to hereafter as 'the Roundtable'), an initiative that involves business and civil society actors and "was formed in 2004 with the objective of promoting the growth and use of sustainable oil palm products through credible global standards and engagement of stakeholders" (RSPO 2013); and (2) the Bangladesh Accord on Fire and Building Safety ('the Accord'), "an independent, legally binding agreement between brands and trade unions designed to work towards a safe and healthy Bangladeshi Ready-Made Garment Industry" (Bangladesh Accord 2016). Both initiatives are set in contexts characterized by significant instability, difference and disagreement in relation to wicked governance issues. We examine not just the initiatives but also other actors which engage with them (often in adversarial ways) while seeking to advance sometimes radically different governance approaches. The aim of the paper is twofold:

(1) To map the different kinds of adversarial relations involved in connection with the issues meant to be governed by the two multi-stakeholder initiatives; and

(2) To understand how these adversarial relations are meant to affect the hegemonic project of the multistakeholder initiatives. For example, some adversaries may still work to improve the provisional hegemony, whether from within or without the initiative, while 
other adversaries may want to advance a radically different counter-hegemony.

We find adversarial relations in relation to the two multistakeholder initiatives to take six main shapes, affecting the hegemonic projects in different ways: (1) competing regulatory initiatives; (2) pressure-response relations within the multi-stakeholder initiatives; (3) pressure-response relations between NGOs and states through multi-stakeholder initiatives; (4) collaboration and competition between multistakeholder initiatives and states; (5) pressure-response relations between civil society actors and multi-stakeholder initiatives; and (6) counter-hegemonic movements against multi-stakeholder initiatives as hegemonic projects. Based on these findings, we conclude that we should not examine democracy or politics only within single multi-stakeholder initiatives, but rather study how issue areas are regulated through both collaborative and adversarial interactions between many different legitimate actors.

The structure of the paper is as follows: In the first section we review the literature on multi-stakeholder initiatives and critiques thereof. We then introduce agonistic pluralism as our main theoretical grounding, which allows us to frame multi-stakeholder initiatives as hegemonic projects seeking to establish consensus and to examine the role of dissensus and adversarial relations attached to the initiatives. In the next section we identify and analyse the different patterns of adversarial relationships linked to the Roundtable and the Accord. In the concluding section we discuss how the differences between the two cases provide insights about multi-stakeholder initiatives, dissensus and democracy.

\section{Multi-stakeholder Initiatives}

The governance of the geographically dispersed supply chains of multinational corporations (MNCs) is increasingly organized through self-regulatory and horizontal configurations. These configurations are often modelled on the logic of market relations whereby multiple stakeholders consult, negotiate and compete over deployment of various instruments of authority in the form of codes, guidelines, standards and labels, which most often lack a coercive backing of state regulation (Blowfield 2005, Shamir 2011). The central idea is that more legitimate decisions will somehow arise "through open and reasoned argument, free from manipulation and the exercise of power" (Bäckstrand et al. 2010, p. 5). These governance systems derive their authority from private actors and tend to exclude state actors from their decision-making processes; such deliberative approaches to democracy are presented as dependent not on the state, but rather on "the discursive quality of collective decision-making"
(Schouten et al. 2012, p. 43). The output of these arrangements is positioned as private/corporate political responsibilities that relate to "the protection, implementation, and facilitation of citizenship rights which include civil, social, and political rights" (Schrempf-Stirling 2018, p. 2).

These post-political regulation arrangements build on the logic that the corporation and other stakeholders can agree on joint commitments and find mutually beneficial solutions. Identified drivers include: (1) proactively avoiding the risk of establishment of coercive state regulation of corporate activities (Shamir 2011, Garsten and Jacobsson 2013); and (2) reactively filling governance gaps when governments are not willing or not able to fill their regulatory role (Fransen and Kolk 2007, Mena and Palazzo 2012). In these arrangements, "law" is understood as a shared problem-solving process coded by notions such as "multi-party cooperation", "constructive dialogue", "multistakeholder consultation", "roundtables", "task sharing" and "democratic participation" rather than an ordering activity (Shamir 2008, p. 7). The output typically is not legally binding obligations but various voluntary compliance mechanisms. In such arrangements, "the legitimacy of soft law standards depends on the democratic control of third-parties and the ability [of the arrangement]...to impose formal or informal sanctions" (Mena and Palazzo 2012, p. 533).

One of the foremost voluntary compliance arrangements which explicitly deals with global governance of supply chains is multi-stakeholder initiatives, here defined as "private governance mechanisms involving corporations, civil society organizations, and sometimes other actors, such as governments, academia or unions, to cope with social and environmental challenges across industries and on a global scale" (Mena and Palazzo 2012, p. 528). In political CSR literature, multi-stakeholder initiatives are framed as one of the most potent models of global governance building on democratic legitimacy beyond the nation state (Palazzo and Scherer 2006; Scherer and Palazzo 2007), transposing the Habermasian deliberative democracy idea to the interaction between corporations and other stakeholders of the same issue. In this literature, a consensual orientation is considered pivotal as consensus "signals the ability and willingness of the involved actors to change their position on the basis of convincing reasons. If participants are willing to potentially change their position, they would show that they are motivated to cooperate for the common ground. Consensual decisions, therefore, are considered to be more reasonable (i.e. reason-based) and more legitimate (Mena and Palazzo 2012, p. 540). As pointed out by Whelan (2013, p. 756), among academic works on multi-stakeholder initiatives, the clearest support for consensual decision-making between corporate and civil society actors has come from the political CSR literature (e.g., Scherer and Palazzo 2007). 
There have been various critiques of both political CSR as a theoretical idea as well as the empirical realities of deliberative democracy and consensual decision-making of private governance systems. Authors such as Banerjee (2014) and Levy and Kaplan (2008) point to how, in the absence of any global monitoring and enforcement mechanisms, CSR evolves into a privatized system that in its governance completely lacks public accountability. Banerjee (2014) draws on Mouffe when arguing that due to the legal construction of the corporation, the tension between the corporate legal forms and democratic participation is irredeemable because the "main question for democratic politics is not how to eliminate power but how to constitute forms of power more compatible with democratic values" (Mouffe 2000, p. 100). But in the post-political discourse of political CSR and multi-stakeholder initiatives, it is taken for granted that society has reached a stage where antagonisms between the economic and the social are transcended with little space left for the articulation of differing interpretations (Garsten and Jacobsson 2007).

Another issue lies in the lack of engagement with unequal power dynamics in multi-stakeholder initiatives. At least two clear limits to the power of civil society in arrangements drawing on deliberative CSR need to be kept in mind. First, NGOs as the token for civil society representation cannot a priori be assumed to represent interests of marginalized communities (Banerjee 2014). The arrangements are often non-transparent about which actors are granted stakeholder status, and ill-defined in terms of the representation and legitimacy they generate (Blühdorn 2013). Second, the outcomes of NGO strategies are neither necessarily beneficial to the communities they are posited to represent nor necessarily identified with the common good, as NGOs also pursue partial, positioned objectives (Swyngedouw 2005). Swyngedouw (2005) points to how such arrangements are contradictory because while they empower civil society they also contribute to the democratic deficit.

Even proponents of Habermasian political CSR, such as Mena and Palazzo (2012, p. 540) acknowledge that "in real political discourse...[multi-stakeholder initiatives] operate in a normatively fragmented landscape, bringing together a multitude of actors...with conflicting moral, economic, and political objectives", which "make a consensus highly unlikely". To date, three theoretical approaches to discuss non-consensual patterns in/with multi-stakeholder initiatives have received some attention in relation to the political CSR debate. First, the critical strand of deliberative democracy, as notably advanced by Dryzek (2000), has been used by some authors to challenge the notion that multi-stakeholder initiatives would be more democratic than unregulated interaction (Baur and Arenas 2014) and/or to complement the consensus orientation of such initiatives with an acknowledgement of conflict resolution patterns driven by a search for 'meta-consensus' (Arenas et al. 2017). Second, several neo-Gramscian studies have shown how various multistakeholder standard-setting efforts in contested value regimes have accommodated some of the demands from reformist NGOs while still prioritizing industry interests of the hegemonic bloc, involving incremental realignments and gradual transformation to marginally more sustainable behaviour (Levy et al. 2010, 2016; Moog et al. 2015). Third, some relevant studies, although not focused on multi-stakeholder initiatives per se, have drawn on conceptualizations of dissensus from Laclau and Mouffe (Edward and Willmott 2013), Mouffe (Burchell and Cook 2013; Dawkins 2015) and Rancière (Brown and Tregidga 2017). In the next section, we introduce Mouffe's agonistic pluralism which we find a useful framing for illuminating dissensus in relation to multi-stakeholder initiatives.

\section{Agonistic Pluralism}

Mouffe's theorization of agonistic pluralism draws on her previous work with Laclau, particularly their book Hegemony and Socialist Strategy (Laclau and Mouffe 1985). In order to understand the post-Marxist, neo-Gramscian understanding of politics they propose, it is important to introduce their two central concepts, antagonism and hegemony. Antagonism refers to the ever-present possibility of conflict, argued to be an ineradicable dimension of political life. In Mouffe's terminology this ineradicable dimension is what defines 'the political' as distinguished from 'politics', which simply refers to all the practices that aim to organize human coexistence (Mouffe 2000, 2005). Seeing antagonism as ineradicable has several important implications in questioning Habermasian deliberative democracy: (1) it invites an understanding according to which most complex political conflicts cannot be tackled through rational solutions, and (2) it denies the possibility of any social order that would be based on full consensus. Thus, the ineradicability of antagonism implies that every social order is contingent upon certain power relations, and not based on an ultimate rational ground. The concept of hegemony refers to the stabilization of a social order; it is understood as "a stabilization of power...that always entails some form of exclusion" (Mouffe 1999, p. 756). As the stabilization cannot eradicate antagonism, it simply excludes those who do not subscribe to it - and thus may attempt to launch a counter-hegemony. As an example, Mouffe (2013,pp. 131-132) argues that "the present state of globalization, far from being 'natural', is the result of a neo-liberal hegemony, and it is structured through specific relations of power [which] means that it can be challenged and transformed, and that alternatives are indeed available".

It is in this context of the ever-present possibility of antagonism that Mouffe has elaborated her agonistic 
understanding of democracy. Agonism refers to "a we/they relation where the conflicting parties, although acknowledging that there is no rational solution to their conflict, nevertheless recognize the legitimacy of their opponents" (Mouffe 2005, p. 20). In this context agonistic pluralism can be seen to encourage development of political spaces that facilitate difference and debate rather than consensus. This recognizes the centrality of conflict within the democratic process, affirming conflict as strength rather than weakness (Burchell and Cook 2013). Adversaries to a hegemonic order confront that order through "counter-hegemonic practices, which attempt to disarticulate the existing order so as to establish another form of hegemony" (Mouffe 2013, p. 132). Thus, challenging the existing order, for Mouffe, is largely a matter of unsettling the hegemonic discourse that this order is based upon: by targeting the discourse's nodal points and giving different meanings to key floating signifiers (Laclau and Mouffe 1985), a disarticulation and rearticulation of discourse can be achieved (Mouffe 2015), one that may ultimately become hegemonic. Agonistic relations can be understood as quite radical-as they are characterized by a struggle for hegemony-but with mutual recognition of legitimacy between the adversaries.

Mouffe (2000) takes issue with Habermasian deliberative democracy, particularly noting the fundamental contradiction between the political need of drawing a frontier between 'us' and 'them', on the one hand, and both the preconditions (ideal speech situation) and objective (consensus without exclusion) of deliberative democracy, on the other. In other words, establishing a space in which ideal speech and consensus without exclusion would be possible entails excluding others outside of this space. Thus, when thinking about multi-stakeholder initiatives as collaborative arrangements aiming for shared objectives for all parties, the space of 'democracy' cannot be restricted to within the initiative itself. Rather, following Gramsci as reframed by Laclau and Mouffe (1985, pp. 161-162), radical democratic action implies a 'war of position' in multiple political spaces, and for this counter-hegemonic action to become powerful, a chain of equivalence between different struggles at different levels needs to be articulated. This is why different ways of engaging within and with multi-stakeholder initiatives need to be considered when examining their political and democratic effects.

\section{Research Methods and Case Descriptions}

Since Mouffe (1999) has explicitly discussed agonistic pluralism as a critique of Habermasian deliberative democracy, transposing her arguments to a critique of Habermas-inspired political CSR is promising (as also hinted by Edward and Willmott 2013; Burchell and Cook 2013;
Dawkins 2015). This approach invites an understanding of multi-stakeholder initiatives as hegemonic projects, to the extent that their aim is to reach consensus across a broad representation of stakeholders, i.e. to establish what Mouffe (1999, p. 756) calls a "provisional hegemony". Multi-stakeholder initiatives are rarely fully successful as hegemonic projects because either they struggle at reaching a broad consensus internally or they are strongly contested externally—or both. In this paper, we pay particular attention to dissensus and adversarial relations both within the multistakeholder initiatives and between these initiatives and other actors. Our case studies of the Roundtable and the Accord are delimited timewise until the summer of 2016. We have continued following what happened in both contexts since then (until March 2019), but not in as systematic a manner although we do make some reference to some more recent developments. The material studied for each case is presented in Table 1.

The two cases discussed in this paper were first studied separately by the two co-authors, with a different research design but similarly inspired by discourse theory (Laclau and Mouffe 1985). The research is linked to two separate ongoing studies by the authors of this paper (Fougère \& Solitander). Fougère has been studying palm oil-related sustainability issues since 2012, first looking into the adversarial relationship between Greenpeace and Neste Oil, and from there gradually extending the focus to many other relevant stakeholders, with a particular interest in NGO expressions of dissent with the Roundtable. What struck him in this case is how much dissent there seemed to be in relation with a regulatory arrangement that was supposed to be consensus driven. Solitander has been collecting data on global justice movements related to the ready-made garment sector since 2012, with a particular interest in struggles within global justice networks dealing with issues around labour rights. The case of the Accord proved a site of contested and agonistic power relations challenging an image of consensus, not only through the historical antagonistic relations between corporations and labour/NGOs or between actors in the North and the Global South, but also through certain tensions between labour and Western NGOs.

Our typology of patterns was developed through four research stages. First, Fougère studied the case of the Roundtable, relying on accounts from various informant stakeholders, official web pages of many of the most important actors engaging with the Roundtable from within and without, and relevant academic studies on it (see Table 1). This first analysis of adversarial relations in relation to the Roundtable generated the first five categories of adversarial relations patterns. The two patterns that were initially most striking were the competition between soft law standards (pattern 1 below) and the pressure-response relations between civil society actors and the Roundtable (pattern 5 below). Accounts from 


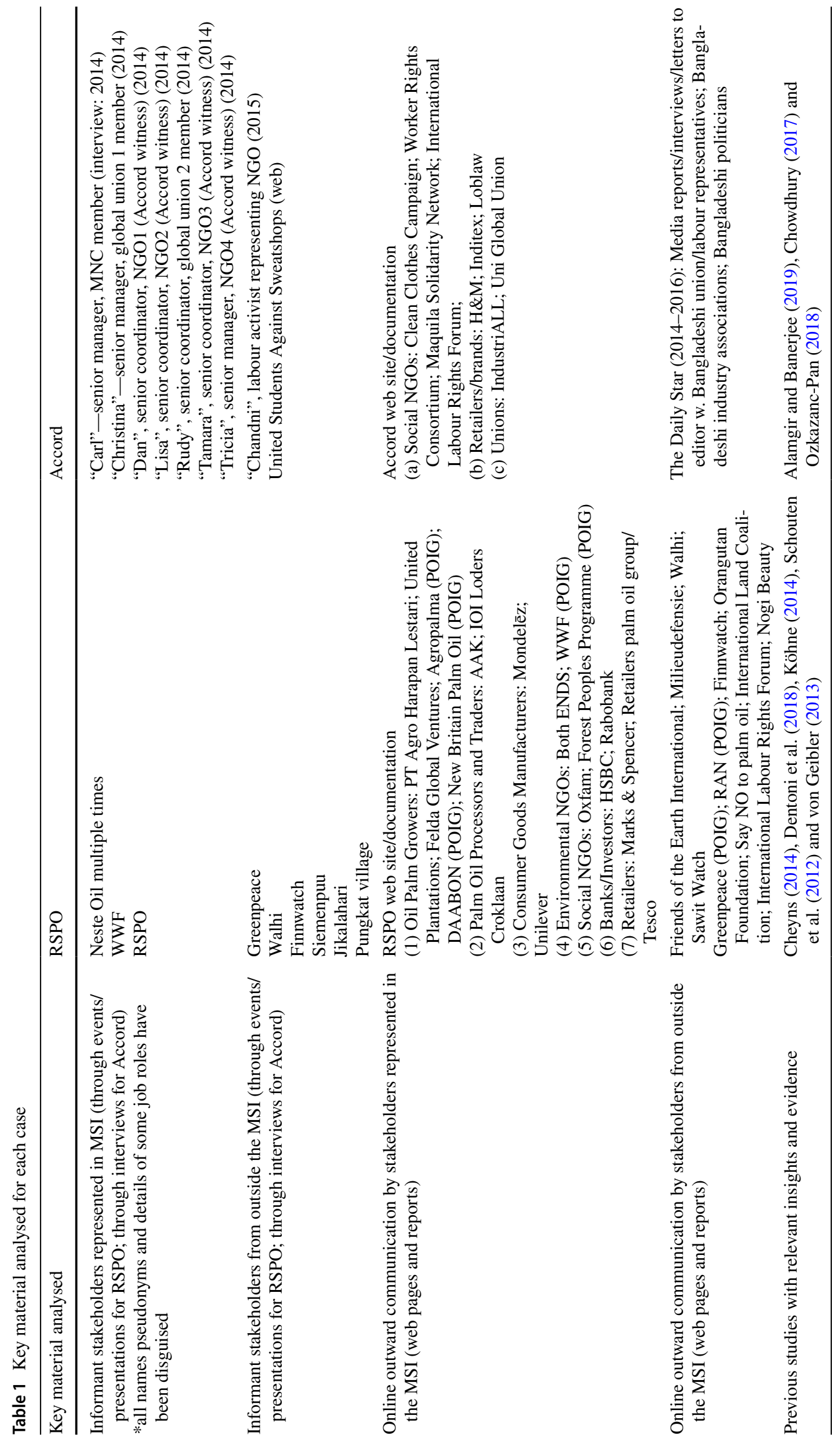


the adversarial civil society actors in turn helped to reach a deeper understanding of pressure-response relations within the Roundtable (pattern 2 below) and pressure-response relations between civil society actors and states through the Roundtable (pattern 3 below). Finally, examining further the relations between the Roundtable and states led to finding out that there is both collaboration and competition between the Roundtable and the state of Indonesia (pattern 4 below).

In a second stage, Solitander, who had been collecting data for their own case study of the Accord, analysed whether the identified patterns were visible in relation to the Accord, and did identify similar patterns, in ways found to be interesting enough for producing a study based on the two cases. In a third stage, the co-authors discussed whether other adversarial relations are relevant, in one or the other case, leading to the sixth category on counter-hegemonic movement. This addition was suggested after Fougère conducted a discourse analysis on the palm oil case, looking systematically into the nodal points, empty signifiers and meanings ascribed to floating signifiers in three distinct powerful discourses on palm oil and sustainability. After this the Accord material was re-analysed from the counterhegemonic perspective. Finally, in a fourth stage, each of the six patterns of adversarial relations was more sharply characterized in terms of Mouffe's agonistic pluralism, with the insight that there are three main kinds of adversarial relations, that one of them, 'competition', is not agonistic, while the other two, 'pressure-response' and 'counter-hegemonic', are.

The data for the two cases were collected separately and with different research designs, although the key material used for both cases can be categorized in five main categories (see Table 1). The Accord data contain in-depth semistructured interviews with actors from inside and outside the initiative, whereas the Roundtable data are mostly based on publicly available accounts and discussions with expert informants in public. Thus, there are some significant differences, notably relating to the need to anonymize only those informants related to the Accord. While informants on both sides referred to adversarial relationships in their accounts, which entails some sensitive information, the Roundtablerelated informants did this in public with the objective of getting their voice heard as broadly as possible. But while the material we analysed was of somewhat different kinds in each case, the spirit in which we read the material to identify patterns of adversarial relations was very similar, a critical discourse perspective which we have had experience in deploying together in previous joint work. This, together with multiple sources of data enabling some degree of triangulation in both cases, alleviated some of the epistemic tensions caused by combing the data into one studyalthough we do acknowledge the different sources of data as a limitation.

\section{The Roundtable on Sustainable Palm Oil}

The palm oil sustainability issue has emerged mainly as a result of the very significant growth in the demand for palm oil, notably for industrial food in emerging economies such as India and China) This fast growth in demand has led to the need for new oil palm plantations, notably in Indonesia (over $50 \%$ of current global palm oil production). Problematic impacts of the new plantations include heightened greenhouse gas emissions, biodiversity loss, endangered species, livelihoods loss for indigenous and/or local communities, land disputes, and other violations of (labour, land and human) rights (see e.g., Cramb and McCarthy 2016).

As a response to civil society pressure about these environmental and social impacts, the Roundtable was founded in 2004 with the explicit objective "of promoting the growth and use of sustainable oil palm products through credible global standards and engagement of stakeholders" (e.g. RSPO 2015). The Roundtable classifies its different members as belonging to seven main categories: (1) Oil Palm Growers; (2) Palm Oil Processors and Traders; (3) Consumer Goods Manufacturers; (4) Environmental NGOs; (5) Social NGOs; (6) Banks/Investors; and (7) Retailers (RSPO 2016a). While corporations clearly dominate the membership of the Roundtable, this unevenness is less marked in its board composition, which is made up of four members of the Oil Palm Growers category (with "one representative each for Malaysia, Indonesia, the smallholder sector and the "Rest of the World"') and two members for each other stakeholder category (RSPO 2016b).

Within business and society literature, a number of articles have noted the relative weakness of the Roundtable, finding it to display low 'deliberative capacity' (Schouten et al. 2012) and a lack of inclusiveness, with large company interests over-represented (Dentoni et al. 2018; von Geibler 2013). The Roundtable has also been found to suppress bottom-up discussion of crucial tensions (Cheyns 2014). Explicit calls for opening a space for expression of dissent within the Roundtable have been made (Cheyns 2014; Köhne 2014). It has also been noted that many actors have taken adversarial roles, putting pressure on the Roundtable from outside (Dentoni et al. 2018; von Geibler 2013).

\section{The Bangladesh Accord}

The Accord is a global labour-led arrangement that was founded by a coalition of NGOs and unions who were dissatisfied with the impotence of business-led multi-stakeholder initiatives and CSR at large. In its initial form, dating to 2010, it was largely rejected by multinational brands and it only became a widely accepted arrangement due to the Rana Plaza collapse in 2013, which killed 1130 workers with over 2500 injured. The Accord is a private governance 
mechanism negotiated between multinational brands and retailers, global (Western) trade unions and NGOs. The Accord consists of six key components (Bangladesh Accord 2016): (1) a 5 year legally binding agreement between brands and trade unions to ensure a safe working environment in the Bangladeshi ready-made garment industry; (2) running an independent inspection programme supported by brands and involving trade unions; (3) public disclosure of factories, inspection reports and corrective action plans; (4) commitments by signatory firms to ensure sufficient funds are available for remediation of factories and to maintain sourcing relationships; (5) establishment of democratically elected workers committees in all factories to identify and act on health and safety risks; and (6) worker empowerment through training programmes, establishment of complaints mechanism and ensuring workers the right to refuse unsafe work. It is noteworthy that the last two points diverge from a narrow focus on health and safety to include the larger issue of workers' rights. Yet the Accord does not critically address any issue about compensation for Rana Plaza survivors or family of dead workers. Additionally, for the Accord 'worker empowerment' does not carry much meaning outside of its relation to safety training programmes.

The Accord is a tripartite agreement between global unions (IndustriALL, the global union representing textile workers and UNI global union, representing retail workers), global brands (in 2016 around 200 brands, retailers and importers, dominantly but not exclusively from Europe) and (IndustriALL affiliated) Bangladeshi unions. The Accord purposely excludes Bangladeshi factory firms based on "perceived 'obstructionism"” (Alamgir and Banerjee 2019, p. 277).

Western NGOs, US-based Workers' Rights Consortium (WRC) and International Labour Rights Forum (ILRF), Netherlands-based Clean Clothes Campaign (CCC) and Canadian-based Maquila Solidarity Network (MSN) also have played an active role in the establishment and governance of the Accord and are so-called 'witness signatories' (Tamara).

The main governing body is the steering committee chaired by the ILO, comprising of three brand members and three union members with two representing global unions, IndustriALL and UNI respectively, and one local Bangladeshi union that is affiliated to IndustriALL. Additionally, two of the NGO 'witness signatories' (Workers' Rights Consortium and Clean Clothes Campaign), have attendance rights and actively participate in all steering committee meetings.

Despite having a legally binding component (arbitration process) the Accord is a clear example of a private governance mechanism that explicitly derives its authority from the involvement of the private actors and the global unions while clearly excluding state actors (most notably the Bangladeshi government) from all its decision-making and governance processes.

The Accord has many characteristics of what Whelan (2013, p. 760) calls dissensual CSR, which "is associated with the corporate concern to actively seek out, acknowledge, and/or publicize, some sort of corporate-civil society disagreement". As Whelan (2013) points out, while the ideas of dissensus and consensus are analytically separate, they are not mutually exclusive or sequentially unrelated. The cases of Rana Plaza and the Accord have been critically analysed elsewhere. Alamgir and Banerjee (2019) show how the Accord is a compliance regime affecting various unrepresented stakeholders (particularly garment workers, nonaffiliated unions, and factories), Chowdhury (2017) focuses on the influence of elite NGOs (in the Accord) on withholding compensation for Rana Plaza victims, and OzkazancPan (2018) discusses how the Accord reproduces gendered neocolonial relations. While these contributions recognize the Accord as a hegemonic project, they largely focus on the lived experience of victims and labour actors marginalized by the Accord rather than those of the actors involved in the Accord. In the following section, we identify and analyse patterns of the dissensus and adversarial relationships linked to the multi-stakeholder initiatives.

\section{Patterns of Adversarial Relations}

We consider multi-stakeholder initiatives as hegemonic projects insofar as they claim to represent the stakeholders and work through consensus, ensuring stability for elite business interests. We identify three 'ideal types' of adversarial relations: (1) competing, where relations reproduce a similar regulatory logic as the multi-stakeholder initiative; (2) pressure-response, where one objective is to 'improve' multi-stakeholder standards while at the same time exposing how problematic they are; and (3) counter-hegemonic, where the objective is to undermine the multi-stakeholder initiative and advance a radically different project. Competing relations lack basic antagonism, instead they contribute to a neutral, post-political vision (Garsten and Jacobsson 2007) in line with a liberal understanding of adversaries, i.e. "merely a competition among elites" (Mouffe 2005, p. 21). Thus, Mouffe's (1999) agonistic notion of 'legitimate adversary' can only be applied to the pressure-response and counter-hegemonic types of relations. In our study of the two multi-stakeholder initiatives, we identify six major patterns of adversarial relations, two of which (1 and 4) are liberal and the other four of which are agonistic: (1) competing regulatory initiatives; (2) pressure-response relations within the multi-stakeholder initiatives; (3) pressure-response relations between NGOs and states through multi-stakeholder initiatives; (4) collaboration and competition between 
multi-stakeholder initiatives and states; (5) pressureresponse relations between civil society actors and multistakeholder initiatives; and (6) counter-hegemonic movements against multi-stakeholder initiatives as hegemonic projects. The actors involved in each of these relational patterns are described in Fig. 1.

\section{Competing Regulatory Initiatives}

The governance of social and environmental compliance in the palm oil and global textile supply chain are telling illustrations of the emergence of a market of authorities (Shamir 2008). Several other legitimacy providers in relation to both the Roundtable and the Accord have emerged and exist. For the Roundtable, competing certifications include the International Sustainability \& Carbon Certification (ISCC) and the Sustainable Agriculture Network/Rainforest Alliance (SAN/RA), and, since 2013, the Palm Oil Innovation Group (POIG). The latter is a constructive attempt to improve the Roundtable approach based on 'credibility', not to oppose it, even though it involves two key actors which before 2013 were very critical of the Roundtable and part of the broad counter-hegemonic movement: Greenpeace and the Rainforest Action Network (RAN). As the founders of the Palm Oil Innovation Group (which also include Roundtable members WWF, Forest Peoples Programme, DAABON, Agropalma, and New Britain Palm Oil) claimed in a joint statement (RAN 2013):

The palm oil industry has suffered from a bad reputation from its association with forest destruction and exploitation. We are building a strong case that palm oil does not need to be linked to forest destruction and exploitation. From producers and traders, through to palm oil consumers, we are creating an approach that can be replicated across the industry, and which will increase demand for responsible palm oil. Our intention is to build on the Roundtable's standards and commitments...

As some commentators have pointed out, the creation of the Palm Oil Innovation Group came as a result of "growing criticism of [the Roundtable] - from NGOs and some companies-about its alleged lack of ambition... with companies such as Sime Darby and United Plantations saying the new principles had gone too far, and others claiming they were still too weak" (CorporateRegister 2013).

Similarly, for social compliance within the readymade garment sector and in relation to the Accord, there are a myriad of competing soft law initiatives including SA8000, Business Social Compliance Initiative (BSCI), Fair Wear Foundation (FWF), Fair Labour Association (FLA), Ethical Trading Initiative (ETI), Child Labour Free, and the ILO's Better Work Bangladesh Programme (BWB). Additionally there are wider industry initiatives that cover garments such as the Worldwide Responsible Accredited Production (WRAP), and the Global Social Compliance Programme (GSCP). But the mechanism that clearly competes directly with the Accord is the Alliance Fire Safety and Structural Integrity Standard, set up by North American brands (most notably GAP and Walmart) who opposed the legally binding aspect of the Accord and the involvement of global unions in "supply chain matters that are appropriately left to retailers, suppliers and government" (Walmart, Press release, May 14, 2013). Both the Alliance and the Accord articulate their relationship as a matter of 'competing'. Additionally, the Rana Plaza collapse gave birth to a Bangladeshi national partnership, the National Tripartite Plan of Action on Fire Safety and Structural Integrity in the garment Sector of Bangladesh (NTPA), which bears some resemblance to a multistakeholder initiative as it was signed by the Bangladeshi
Fig. 1 Six patterns of adversarial relations in and with multi-stakeholder initiatives
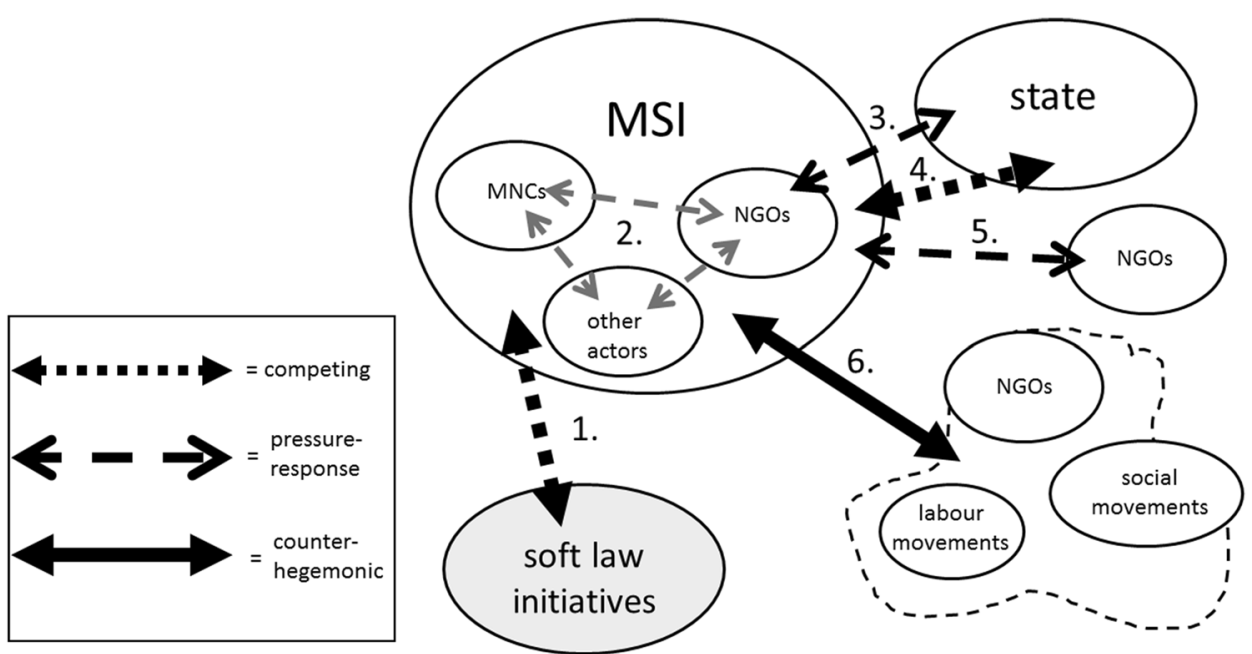
Ministry of Labour and Employment, national unions, and factory owner organizations, and facilitated by the ILO.

These competing initiatives are defined in what some discourse theorists call a "logic of equivalence" (see e.g. Torfing 1999, p. 301) since they also mostly rely on certification, labels and/or inspections. Thus, while they may be framed as adversaries in a liberal sense, they are not the type of adversaries that Mouffe $(2005,2013)$ writes about in the context of agonistic pluralism.

\section{Pressure-Response Relations Within the Multi-stakeholder Initiatives}

Both studied multi-stakeholder initiatives include a number of civil society actors, unions and NGOs that do not feel that they have just been co-opted (cf. Burchell and Cook 2013) but rather that they participate in order to give voice to marginalized people (such as poor farmers and oppressed textile workers) so that they can express complaints about companies which are often members of the multi-stakeholder initiatives, and improving these initiatives from within by acting as watchdogs of the enforcement of sustainability and/ or labour standards. These types of actors clearly qualify as legitimate adversaries to business interests or even the multi-stakeholder initiatives, with some of them remaining outside of the initiatives and others attempting to influence the initiatives from within.

In relation to the palm oil sustainability case, Friends of the Earth Indonesia aka Walhi, while not a member of the Roundtable, is closely tied with the social NGO Sawit Watch, which it co-founded to support the rights of indigenous and local communities in oil palm plantations areas. Sawit Watch has provided "financial and logistical support" to the creation of the SPKS farmers' union, meant to "promote the representation of family farmers in [the Roundtable]" (Cheyns 2014, p. 443). From 2006 to 2012 Sawit Watch was a member of the Roundtable's Executive Board while knowing well that it mainly "is a system for market interests" (Widjaya 2013). Its ongoing participation in the Roundtable is mainly meant to enable poor farmers to complain to the Roundtable about large plantation companies it has certified (see Cheyns 2014) and to improve RSPO from within by acting as a watchdog of work conditions at certified palm oil plantations (see Sawit Watch and ILRF 2013). Here, Friends of the Earth International, Walhi, Sawit Watch and the farmers' union SPKS are all closely linked and networked with the broader counter-hegemonic movement that mainly involves NGOs that are not Roundtable members (such as Friends of the Earth or Greenpeace).

The NGOs and unions are consequential in positioning the Accord as different from the self-regulated voluntary CSR activities of the firms. In the communications of both Clean Clothes Campaign and IndustriAll CSR is established as an enabler of social oppression and a direct point of blame for Rana Plaza. To Clean Clothes Campaign (CCC 2013), CSR is a "self-regulatory approach that... has failed to protect the safety of workers in Bangladesh: company-controlled factory monitoring with no transparency, no role for workers or their trade unions, no commitment to pay prices to suppliers that make it feasible for them operate responsibly, and no binding commitments of any kind". IndustriAll sees most multi-stakeholder initiatives as just another form of impotent CSR: "the results [of multi-stakeholder initiatives] are often no better than unilateral company efforts, relying as they do on similar auditing methods and failing to address the root causes - the supply chain production model itself" (Holdcroft 2015, p. 95). In the union discourse the Accord is posited as something different from usual multistakeholder initiatives and is instead established as a "new model of cooperation".

Thus, there is no consensus among actors involved in the Accord. The unions and NGOs construct the Accord as an arena through which it is possible to contest some of the central meanings of CSR. One of the union representatives described the Accord as a possibility to "deconstruct the power relationships" (Rudy). This is in line with Burchell and Cook's (2013) analysis on the role of civil society organizations in contesting the meaning and language of CSR. The enduring, completely different views on CSR held by unions and firms involved in the Accord cannot be resolved through deliberation and rational discussion aiming for consensus (Mouffe 1999), as is evident in IndustriAll seeing the root problem as the supply chain production model itself. There will be no consensus between the actors on how to deal with or even recognize the root causes for events like Rana Plaza. For the unions, the possibility of conflict with the brands and factory owners does not disappear as a result of their engagement in this process. At the same time the interactions within the Accord do not build on antagonism, the brands are seen as legitimate actors with whom to have a dialogue in the political space of the Accord.

\section{Pressure-Response Relations Between NGOs and States Through Multi-stakeholder Initiatives}

Both cases contain civil society actors that partake in the multi-stakeholder initiative in order to put pressure on governments (especially Indonesia and Bangladesh) to improve and implement state regulation on the national level.

As Widjaya (2013) puts it, the main purpose of Sawit Watch being an Executive Board member of the Roundtable was "to put pressure on the Indonesian government in order to improve regulation in Indonesia". This is in line with Köhne's (2014) study of how different communities and movements try to leverage the Roundtable as a political resource in land conflicts. To some extent, this pressure 
exercised through the Roundtable can be argued to have contributed to the birth of the ISPO (Indonesian Sustainable Palm Oil) regulation which is "a policy adopted by... the Government of Indonesia with the aim to improve the competitiveness of the Indonesian palm oil on the global market and contribute to the objective...to reduce greenhouse gases emissions and draw attention to environmental issues" (ISPO 2014). Hospes (2014) shows how the birth of ISPO has a great deal to do with the exclusion of the association of Indonesian palm oil plantation companies (Gapki) at various stages of the Roundtable process, and Gapki's "feelings of disadvantage by the course [the Rountable's] development took" (ibid.: 429). According to Widjaya (2013), ISPO as a standard is "funny and weird" (sic) since it considers the Roundtable standards to be too heavy and has resulted in lowering standards based on the demand from companies. ISPO is mandatory to the extent that every company that grows oil palms in Indonesia has to be a member, but the criteria applied are largely voluntary, and have been shown to be clearly less demanding than those of the Roundtable, notably when it comes to such crucial aspects as commitment to transparency, land compensation and expansion of plantations on peatlands (see Hospes 2014). Not surprisingly, Walhi and Sawit Watch are even more critical of ISPO than they are of the Rountable, as ISPO is even more industry friendly. Thus, their struggle for contributing to improvements in the Indonesian governmental regulation continues, even though Sawit Watch has resigned as an Executive Board member of the Roundtable (Widjaya 2013).

Western union and NGO representatives present the Accord as leverage to enforce existing Bangladeshi law, as well as a possibility to empower workers and contribute to more mature industrial relations. The Accord is seen as a temporal solution for state failure where the end goal is establishment of functioning state enforcement of labour laws. As one of the global union representatives puts it, "the ultimate aim [of the Accord] is to have proper governments with proper, enforceable laws that are policed." (Christina) This is also a view expressed by the major brands, albeit on different ideological grounds: "local unions are now more functional and empowered to negotiate directly with the employers to solve issues or to drive change, and without having to have the hand holding of international organizations... which I see as a clear development for a maturing industry and maturing country in this case." (Carl)

At the same time the Western civil society actors do not see national state regulation as a solution by itself, as a global unions representative notes: "we are no longer in this kind of autarchic nation states where everything happens internally, we're in a globalized capitalistic system of fragmented supply chains.. but [the Accord] is a bit of sort of privatization of state responsibilities but in a context where there is also no clear state to hold supply chains accountable" (Rudy)

\section{Collaboration and Competition Between Multi-stakeholder Initiatives and States}

While multi-stakeholder initiatives are often meant to be 'trisector' (Laasonen et al. 2012), including businesses, civil society organizations and state actors, none of the stakeholder categories of the Roundtable and the Accord is explicitly state related. However, arguably both the Roundtable and the Accord have led to impetus for state-run initiatives in the form of ISPO in Indonesia and the National Tripartite Plan (NTPA) in Bangladesh.

Initially, ISPO was framed as a sort of competitor to the Roundtable, a mandatory initiative that growers in Indonesia have to apply but that is at the same time far less demanding than the Roundtable. Worse, according to many social and environmental NGOs, ISPO was initially created largely in order to encourage members of Gapki and the Indonesian Palm Oil Board to abandon the Roundtable "because Gapki...said that the [Roundtable] principles will impede the development of the industry" (Buckland 2010). So while "ISPO is a government certification scheme.... and as such is legally binding [for] all oil palm producers in Indonesia", its content "is in essence a compilation of all government regulations applied to oil palm plantations" (Gillespie and Harjanthi 2012; see also Hospes 2014) and it has not really brought new regulation to the table, other than by framing itself symbolically as a competitor to the Roundtable.

Beyond this competitive rhetoric, there seems to be a permanent game moving between collaboration and competition, tighter and looser coupling, between the Roundtable on the one hand, and the Indonesian government and Gapki on the other (Hospes 2014). For example, in 2013 the relationship between the Roundtable and ISPO seemed to change as they entered enter into "strategic co-operation", which in its first phase consisted of a "joint study to examine both voluntary international standards and mandatory national standards" (RSPO 2013). Ironically, the ultimate aim of this co-operation seems to be to come up with a higher level "multi-stakeholder platform, where stakeholders such as the Roundtable and ISPO can convene and discuss how to best work together to achieve sustainable palm oil in Indonesia" (RSPO 2013).

The National Tripartite Plan (NTPA) is a plan for "legislation and policy, administrative and practical activities", which "will be the main framework document for improving working conditions in the garment industry in Bangladesh" (ILO 2013). However, the exclusion of the Bangladeshi state actors from the political space of the Accord is noteworthy. The Accord is positioned as a legitimate form of governance due to the failure of the Bangladeshi government to enforce 
its own laws. One of the global union representatives argues that the Accord are "providing resources and capacity for doing the inspections that the government simply isn't able to do" (Christina). It is also clear from the material that the international actors are more willing to grant legitimacy to non-state regulation than Bangladeshi actors. As a Bangladeshi labour activist puts it:

[the Accord] is a form of private market regulation, it's not legislative, it's not law, it's not created through a democratic process, it's a way by which labour is regulating the private market. [In] Bangladesh, we're a sort of post-colonial emerging new nation with weak [legal] infrastructure. It's very easy to, which a lot of global unions do, blame the government. Yes, the government is weak...but the Accord does not help to build local capacity, because they bring engineers, and experts from abroad...If the [Accord] want to close a factory, it was imagined that whatever the Accord said, they would close down the factory. And so understandably the government of Bangladesh said no, not necessarily because they were against workers, but because this bypasses any kind of notion of democracy (Chandni)

The Bangladeshi state is inherently tied to the garment factory owners, and it is estimated that 10 percent of the members of the parliament directly own textile factories, while more have indirect financial interests (Yardley 2013). In this context it is not surprising that the tension between the Accord and the Bangladeshi state has intensified, with the latter critiquing the 'unilateral' approach of the Accord (The Daily Star 2018).

\section{Pressure-Response Relations Between Civil Society Actors and Multi-stakeholder Initiatives}

The pressure from civil society organizations sometimes might contribute to improvements in multi-stakeholder initiatives, as in the case of FSC-watch acting as a watchdog of the Forest Stewardship Council (see Edward and Willmott 2013). Similarly, NGOs such as Greenpeace have contributed to improving the Roundtable through watchdog activities. Examples of successful pressure-response processes affecting big Indonesian plantation companies at the height of Greenpeace watchdog activities include Sinar Mas receiving an ultimatum from the Roundtable in October 2010 (Greenpeace UK 2010) and Duta Palm being kicked out of the Roundtable in May 2013 (Greenpeace UK 2013). Most spectacularly since Greenpeace's partial move to a more constructive approach with the Palm Oil Innovation Group (in late 2013), Roundtable co-founder and board member company IOI was suspended from the Roundtable in 2016 (and later reinstated), following reports from watchdogs (see Taufik 2016).

Even when NGOs act as watchdogs from the outside of the Roundtable, there is a strong sense that they do this as legitimate adversaries. In fact, the legitimacy of adversarial relations is even acknowledged by key Roundtable member Neste Oil, which was the target of a blame and shame campaign by Greenpace leading to its infamous Public Eye People's Award in 2011 (Public Eye 2011). Despite the strong adversarial tone, at the height of the campaign Neste Oil sustainability director Simo Honkanen (2012) framed relations with Greenpeace as characterized by "a good dialogue" with a legitimate, important stakeholder.

The Accord is slightly different since it is not perceived to be a business-dominated initiative. Western NGOs and global unions are not pressurizing the Accord as they largely control it, even though they also recognize that since the Accord was set up, there has been an "increase in repression, retaliation and violence against workers seeking to form unions" (Lisa). Some of the NGOs see themselves as being able to pressure Accord firms through other forums and coalitions where the NGOs are also members (Lisa) but this does not extend to critique of the Accord itself. Instead critical civil society voices have come more from local unions and local labour activists in Bangladesh (Alamgir and Banerjee 2019; Chowdhury 2017), who have expressed concern in relation to: (1) the Accord's lack of long-term capacity building for local (under-resourced) unions, as the safety-focused Accord is felt to take away energy from local organizing and union struggles over wages (Chandni); (2) the bypassing of democratic institutions and questions of dependence and sovereignty (Akter 2017); (3) the dominance of elite Western NGOs and unions; (4) the (non) representation of local Bangladeshi unions; and (5) the silencing of women workers in the multi-stakeholder initiative (Alamgir and Alakavuklar 2018). Local actors and actors most focused on Bangladeshi rights are the ones who seem most concerned with the democracy deficit in these arrangements, whereas the elite Western civil society organizations and global unions show less concern in how they contribute to legitimizing non-state governance systems. The outside local pressure described above has not led to much response by the Accord or its NGO/global unions members. In interviews of members of the Accord, local unions are said to "know how to organize protests" (Tamara) but lack in "greater capacity at the staff level to take on something of [the Accord's] size" (Tricia) and "not understand what the Accord is about" (Rudy). The lack of response to pressure highlights a significant difference with the Roundtable: since the Accord is (global) labour led, it is seen by global unions and Western NGOs as a successful labour alternative to business-dominated multi-stakeholder initiatives, regardless of the persistent concerns of local labour. 


\section{Counter-Hegemonic Movements Against Multi-stakeholder Initiatives as Hegemonic Projects}

Strong counter-hegemonic movements against multi-stakeholder initiatives as hegemonic projects are probably quite rare, as it is unlikely that the initiatives as such would be the main target of opposition. But in the palm oil case, and especially over the period between 2008 and 2013, a powerful opposition movement explicitly targeting the Roundtable managed to establish a chain of equivalence between many different struggles. On the one hand, this counter-hegemonic movement, led by large international NGOs such as Friends of the Earth International and Greenpeace, explicitly targeted the nodal point of the Roundtable, 'credible global standards'. It did so by questioning the credibility of the Roundtable standards through watchdog investigations exposing the certification as greenwash (see FoEI 2009; Greenpeace 2013), and by blaming and shaming large buyers of certified palm oil such as Nestlé and Neste Oil. On the other hand, a characteristic that made the chain of equivalence possible was the nodal point of the counterhegemonic movement, the systematic problematization of 'land-use change'. The focus on land-use change emphasized the key sustainability challenge of preventing conversion of forests and peatlands into plantations, in a way that connected to: (1) global objectives of large climate change and biodiversity campaigning organizations like Greenpeace; (2) 'meso-level' objectives of conservation of regional species in the process of losing their habitat, such as orangutans as a 'flagship species'; and (3) much more local struggles related to air and water pollution, fires, haze, losses of livelihoods, land and labour rights, all of which relate to the land-use change problem.

What kept the largest NGOs of the movement firmly attached to the land-use change framing was their campaigning against palm oil-based biofuels, for which greenhouse gas emissions measurements operationalized based on the concept of 'indirect land-use change' (institutionalized through the Intergovernmental Panel on Climate Change and the EU's Renewable Energy Directive), combined with the 'food vs. fuel' question as part of the development agenda, provided leverage in the struggle against one of the largest buyers of palm oil, Neste Oil. Once it became clear, in 2013, that the EU would reject palm oil-based biofuels by 2020 (as confirmed in an EU Parliament vote in 2017), Greenpeace and the Rainforest Action Network, two of the largest counter-hegemonic NGOs, decided to partially change course by co-founding the Palm Oil Innovation Group, thereby disarticulating the counter-hegemonic discourse by adopting a logic similar to the Roundtable's.

In the case of the Accord, it appears that as a hegemonic project it has been relatively successful in sustaining a chain of equivalence where the interests of the global unions and those of business can both be satisfied. The key here is to see Rana Plaza as the nodal point that mobilizes very different actors around the same project: the magnitude of Rana Plaza has been seized by unions as an opportunity for a serious attempt to improve the enforcement of safety standards in Bangladesh, and it has also forced many Western brands to be on board. Behind this nodal point, however, very different objectives are driven by different actors: the unions seek to drive labour empowerment while the companies are mainly interested in reclaiming their threatened legitimacy in the face of crisis. The global unions also consider the Accord as an attempt to reconfigure CSR discourse (cf. Burchell and Cook 2013) by allocating the onus of responsibility (and some costs) to brands and retailers (rather than on consumers or suppliers). The absolute emphasis on the responsibility of brands and retailers for improving safety conditions at their suppliers' factory units is a departure from how responsibility in the supply chain was constructed before the Accord, when brands where clear in communicating that the responsibility is equally if not more on the factories and local governments. Yet the Accord does not manage to break with what the unions see as hegemonic, status quo-inducing processes: auditing methods that fail to address what should be recognized as the root problem- "the supply chain production model itself" (Holdcroft 2015, p. 95). Until now, this chain of equivalence between different interests and objectives has been sustained and that is one reason why a strong counter-hegemonic movement has not emerged, and why opposition has been fragmented.

\section{Concluding Discussion}

Studying multi-stakeholder initiatives by drawing on agonistic pluralism is not only about showing that there are stakeholders who remain adversarial and attempt to advance a counter-hegemony. On the one hand, the adversarial stakeholders are shown to pragmatically contribute to incremental improvements to the very scheme (e.g., Roundtable certification) whose mission and rationale they otherwise radically undermine. On the other hand, there are competing initiatives, representing a variety of stakeholders, This included the Indonesian state (through the Indonesian Sustainable Palm Oil, ISPO), NGOs like Greenpeace (through the Palm Oil Innovation Group), the Bangladeshi state (through the National Tripartite Plan, NTPA) and North American brands through the Alliance. These competing schemes are articulated overall in a logic of equivalence with the prevailing market-based hegemony, as they choose the same legitimacy game (based on certification or standards) as the Roundtable and the Accord.

A key insight that Mouffe's agonistic pluralism allows for is that when actors engage in hegemonic struggles, their 
identities are likely to change over time as a result. Changes of identity have certainly characterized both hegemonic struggles studied here. For the Roundtable, the need to make the standards more credible, under pressure from watchdogs from within and without, has made them more potent and consequently led to the temporary rejection of key founders (IOI) and more recently the suspension of one of the largest buyers, one of the foremost CSR and UN Global Compact embracing corporations, Nestlé. For the counter-hegemonic palm oil movement, necessary rearticulations of discourses (notably in 2013, due to both the partial resolution of the biofuels issue and the improvements in the credibility of the Roundtable standards) have led to some of the largest actors moving from agonism to liberal competition, with Greenpeace and the Rainforest Action Network focusing on the delivery of more credible standards than the Roundtable's through the Palm Oil Innovation Group. A consequence has been a dislocation of the counter-hegemonic discourse, implying identity changes for all the actors involved, including Friends of the Earth International and local NGOs and movements.

In relation to the Accord, some identity changes related to the larger counter-hegemonic movement of labour rights can be observed. Both global unions and Western NGOs are contradicting their own previous critique of multi-stakeholder initiatives' democracy deficit by supporting the Accord and framing it as labour led rather than business dominated. Yet they know that the Accord does not actually address the 'supply chain production model itself' and its close relation to worker suppression and low wages. In that sense, these actors too seem to have moved from an agonistic stance to (liberal) regulatory competition. But at the same time, the union-NGO coalition that made the Accord possible might help in developing a chain of equivalence between the traditionally divided demands (see Egels-Zandén et al. 2015) of global unions and NGOs on labour rights. Emphasizing these identity changes speaks to the dynamic complexity of agonistic struggles around multi-stakeholder initiatives and challenges the neat perspectives from deliberative, consensus-driven approaches by illuminating the messiness and fluidity of identities and relationships.

When comparing the two cases, it is important to note that the Roundtable has historically been clearly more corporate driven than the Accord. The objective of the Roundtable to develop credible global standards caters especially for the legitimacy interests of large Western buyers, economic interests of traders and social license to operate interests of large plantations. As a result, opposition movements have been strong and there was even a powerful counter-hegemonic chain of equivalence at some point. At the same time, some powerful additional resistance has come from a very different angle, in the name of the national economic interests of the Indonesian and Malaysian states. The Accord, which is firmly positioned as a project driven by global unions, has also met resistance. This resistance was driven by employers' federations and export associations who were not included in the initiative, and to a certain extent by local unions and labour organizers who were not involved in its formal governance. However, this resistance has largely played out in a fragmented way. While expressing their discontent, local unions have been especially weary to align with the same discourse as employers' federations who use 'sovereignty' as a central node of critique of the Accord.

Thus, it appears that the shape of opposition depends on what types of actors have been mainly driving the initiative and/or been included (the Roundtable does not involve formal representation of labour unions for example, assuming these issues can be dealt with by 'social NGOs', and the Accord gives government and local employers observer status only), and what overall objective the initiative has ('credible global standards' vs. 'a safe and sustainable local sector')? When the multi-stakeholder initiative is too clearly business led and has a too clearly industry-friendly objective, the de-democratizing effect is evident: each of the actors involved needs to be convinced they stand to gain from the partnership (Glasbergen 2011), which means that the many stakeholders who cannot see how a business-driven objective might benefit them simply do not take part, and the representativeness of the initiative is very poor. This is the case for the Roundtable, and it is arguably less obvious (but probably valid) for the model multi-stakeholder initiative that FSC has been claimed to be (see Edward and Willmott 2013; Moog et al. 2015).

The Accord is more complex but not less problematic, it is clearly a Western-led initiative driven by global unions and Western NGOs, which for 'pragmatic reasons' excludes government and local business representatives but also unions not affiliated with the global unions; on this basis, any claim that the Accord is representative of the stakeholders would be dubious (see also Alamgir and Banerjee 2019; Chowdhury 2017). Many local unions pragmatically or grudgingly partake even though they are concerned that the technical nature of the Accord takes away resources from the real struggle, i.e., securing the rights to organize. One relevant question would be whether the very involvement of business in multi-stakeholder initiatives makes them by definition undemocratic, as their selfish economic interests can be assumed to drive their participation rather than foremost addressing a societal or/and environmental issue. What is particularly interesting in the case of the Accord is that it shows that when the objective is not framed on the terms of business but (because of an acute crisis in the entire model of production) on the terms of unions with the priority set to safety and labour rights, businesses can remain on board. But this provisional hegemonic stabilization is possible only as long as the Accord relies on certain technical and 
non-radical approaches that reproduce compliance regimes similar to those the MNCs have been using for decades, and the strong emphasis on health and safety also makes possible a marginalization of issues around wage and rights to organize.

Does this mean that the Accord, with its moderate 'success' in keeping (Western) unions, civil society and business on board, is more 'democratic' than the Roundtable? In other words, is a multi-stakeholder initiative that is successful in delivering an impression of democratic legitimacy necessarily governing its issue area in a 'more democratic' way than one whose lack of representativeness and credibility has been exposed by many actors who have de facto had a say in the governance of this issue area? The point here is precisely that we should not look at democracy or politics only internally to single multi-stakeholder initiatives no matter how universal they present themselves to be, but rather study how issue areas are regulated through interactions between a variety of actors who get to have a legitimate voice in this regulation. On this basis, we cannot say whether, among our two cases, one issue area is governed more democratically than the other, but we can problematize concerns that are specific to each of the issue areas. The problems with the Roundtable may be more obvious than those with the Accord, but in relation to the latter, a number of actors seem relatively silenced as a result of the strong chain of equivalence between Western unions, civil society and business. Notably, local unions and Bangladeshi government actors have expressed discontent which does not seem to have been granted the legitimacy it should have. A key concern being that the Accord can be seen to infringe on the sovereignty of Bangladesh much more than the Roundtable does on the sovereignty of Indonesia or Malaysia. Granted, within the global labour movement much of the rationalization for challenging Bangladeshi sovereignty has to do with the priority placed on securing the right to organize for workers. But when Western actors frame temporary de-democratization as an acceptable price to pay for more important objectives, the legitimation of their initiatives through an appeal to democracy inevitably falls apart.

Acknowledgements Open access funding provided by Hanken School of Economics.

\section{Compliance with Ethical Standards}

Conflict of interest Martin Fougère and Nikodemus Solitander declares that they have no conflict of interest.

Ethical Approval No external funding was received for this research. All procedures performed in studies involving human participants were in accordance with the ethical standards of the institutional and national research committees and with the 1964 Helsinki declaration and its later amendments or comparable ethical standards. Informed consent was obtained from all interview subjects included in the study. This article does not contain any studies with animals performed by any of the authors.

Open Access This article is licensed under a Creative Commons Attribution 4.0 International License, which permits use, sharing, adaptation, distribution and reproduction in any medium or format, as long as you give appropriate credit to the original author(s) and the source, provide a link to the Creative Commons licence, and indicate if changes were made. The images or other third party material in this article are included in the article's Creative Commons licence, unless indicated otherwise in a credit line to the material. If material is not included in the article's Creative Commons licence and your intended use is not permitted by statutory regulation or exceeds the permitted use, you will need to obtain permission directly from the copyright holder. To view a copy of this licence, visit http://creativecommons.org/licenses/by/4.0/.

\section{References}

Akter, T. (2017). In the battle between rights and aid. The Daily Star, April 21, 2017. Retrieved December, 2018, from https ://www.thedailystar.net/star-weekend/the-battle-between-right s-and-aid-1393873

Alamgir, F., \& Banerjee, S. B. (2019). Contested compliance regimes in global production networks: Insights from the Bangladesh garment industry. Human Relations, 72(2), 272-297.

Alamgir, F., \& Alakavuklar, O. N. (2018). Compliance codes and women workers' (Mis)representation and (Non)recognition in the apparel industry of Bangladesh. Journal of Business Ethics. https://doi.org/10.1007/s10551-018-4080-2.

Arenas, D., Albareda, L., \& Goodman, J. (2017). Understanding conflict in multi-stakeholder initiatives: Corporate responsibility and deliberation. In Academy of management proceedings (Vol. 2017, p. 15086).

Bäckstrand, K., Khan, J., Kronsell, A., \& Lövbrand, E. (2010). The promise of new modes of environmental governance. In $\mathrm{K}$. Bäckstrand, J. Khan, A. Kronsell, \& E. Lövbrand (Eds.), Environmental politics and deliberative democracy: Examining the promise of new modes of governance (pp. 3-27). Cheltenham: Edward Elgar.

Banerjee, S. B. (2008). Corporate social responsibility: The good, the bad and the ugly. Critical Sociology, 34(1), 51-79.

Banerjee, S. B. (2014). A critical perspective on corporate social responsibility: Towards a global governance framework. Critical Perspectives on International Business, 10(1-2), 84-95.

Banerjee, S. B. (2018). Transnational power and translocal governance: The politics of corporate responsibility. Human Relations, 71(6), 796-821.

Bangladesh Accord. (2016). Web site front page. Retrieved January 7, 2016, from http://bangladeshaccord.org/.

Bartley, T. (2007). Institutional emergence in an era of globalization: The rise of transnational private regulation of labor and environmental conditions. American Journal of Sociology, 113(2), 297-351.

Baur, D., \& Arenas, D. (2014). The value of unregulated businessNGO interaction: A deliberative perspective. Business \& Society, 53(2), 157-186.

Blowfield, M. (2005). Corporate social responsibility: The failing discipline and why it matters for international relations. International Relations, 19(2), 173-191.

Blühdorn, I. (2013). The governance of unsustainability: Ecology and democracy after the post-democratic turn. Environmental Politics, 22(1), 16-36. 
Brown, J., \& Tregidga, H. (2017). Re-politicizing social and environmental accounting through Rancière: On the value of dissensus. Accounting, Organizations and Society, 61, 1-21.

Buckland, H. (2010). Finally! Palm oil companies recognise the value of forests. Retrieved June 4, 2014, from http://www.green peace.org.uk/blog/forests/finally-palm-oil-companies-recog nise-value-forests-20101115.

Burchell, J., \& Cook, J. (2013). CSR, co-optation and resistance: The emergence of new agonistic relations between business and civil society. Journal of Business Ethics, 115, 741-754.

CCC. (2013). The history behind the Bangladesh fire and safety accord. Retrieved July 8, 2013, from https://cleanclothes.org/ resources/background/history-bangladesh-safety-accord.

Cheyns, E. (2014). Making "minority voices" heard in transnational roundtables: The role of local NGOs in reintroducing justice and attachments. Agriculture and Human Values, 31, 439-453.

Cheyns, E., \& Riisgaard, L. (2014). The exercise of power through multi-stakeholder initiatives for sustainable agriculture and its inclusion and exclusion outcomes. Agriculture and Human Values, 31, 409-423.

Chowdhury, R. (2017). The Rana Plaza disaster and the complicit behavior of elite NGOs. Organization, 24(6), 938-949.

CorporateRegister. (2013). New palm oil group aims to shake up RSPO. Retrieved December 22, 2019, from http://www.corpo rateregister.com/news/item/?n=486.

Cramb, R., \& McCarthy, J. F. (Eds.). (2016). The oil palm complex: Smallholders, agribusiness and the State in Indonesia and Malaysia. Singapore: NUS Press.

Dawkins, C. (2015). Agonistic pluralism and stakeholder engagement. Business Ethics Quarterly, 25(1), 1-28.

Dentoni, D., Bitzer, V., \& Schouten, G. (2018). Harnessing wicked problems in multi-stakeholder partnerships. Journal of Business Ethics, 150, 333-356.

Dryzek, J. S. (2000). Deliberative democracy and beyond: Liberals, critics, contestations. Oxford: Oxford University Press.

Edward, P., \& Willmott, H. (2013). Discourse and normative business ethics. In C. Luetge (Ed.), Handbook of the philosophical foundations of business ethics (pp. 549-580). Dortrecht: Springer.

Egels-Zandén, N., Lindberg, K., \& Hyllman, P. (2015). Multiple institutional logics in union-NGO relations: Private labor regulation in the Swedish Clean Clothes Campaign. Business Ethics: A European Review, 24(4), 347-360.

Ehrnström-Fuentes, M. (2016). Delinking legitimacies: A pluriversal perspective on political CSR. Journal of Management Studies, $53(3), 433-462$.

FoEI. (2009). 'Certified' palm oil not a solution. Retrieved May 30, 2014, from http://www.foei.org/press/archive-by-subject/foodsovereignty-press/certified-palm-oil-not-a-solution/.

Fougère, M., \& Solitander, N. (2009). Against corporate responsibility: Critical reflections on thinking, practice, content and consequences. Corporate Social Responsibility and Environmental Management, 16(4), 217-227.

Fransen, L. W., \& Kolk, A. (2007). Global rule-setting for business: A critical analysis of multi-stakeholder standards. Organization, 14(5), 667-684

Frynas, J. G., \& Stephens, S. (2015). Political corporate social responsibility: Reviewing theories and setting new agendas. International Journal of Management Reviews, 17(4), 483-509.

Garsten, C., \& Jacobsson, K. (2007). Corporate globalization, civil society and post-political regulation-Whither democracy. Development Dialogue, 49, 143-157.

Garsten, C., \& Jacobsson, K. (2013). Post-political regulation: Soft power and post-political visions in global governance. Critical Sociology, 39(3), 421-437.

Gillespie, P., \& Harjanthi, S. (2012). ISPO, RSPO: Two sides of the same coin. Retrieved December 22, 2019, from https://sustainabl epalmoilinindonesia.wordpress.com/2013/08/03/ispo-rspo-twosides-of-the-same-coin/.

Glasbergen, P. (2007). Setting the scene: The partnership paradigm in the making. In P. Glasbergen, F. Biermann, \& A. P. J. Mol (Eds.), Partnerships, governance and sustainable development. Cheltenham, UK: Edward Elgar.

Glasbergen, P. (2011). Understanding partnerships for sustainable development analytically: The ladder of partnership activity as a methodological tool. Environmental Policy and Governance, $21(1), 1-13$.

Greenpeace UK. (2010). Sinar Mas gets ultimatum from RSPO over palm oil and deforestation. Retrieved December 22, 2019, from https://www.greenpeace.org/archive-international/en/news/Blogs /makingwaves/sinar-mas-gets-ultimatum-from-rspo-over-palm-/ blog/26480/.

Greenpeace. (2013). Certifying destruction: Why consumer companies need to go beyond the RSPO to stop forest destruction. Retrieved March 2, 2016, from http://www.greenpeace.de/files/publicatio ns/rspo-certifying-destruction.pdf.

Holdcroft, J. (2015). Transforming supply chain industrial relations. International Journal of Labour Research, 7(1/2), 95.

Honkanen, S. (2012). Neste oil and sustainability: Case palm oil. Slides used for a guest lecture, October 42012.

Hospes, O. (2014). Marking the success or end of global multi-stakeholder governance? The rise of national sustainability standards in Indonesia and Brazil for palm oil and soy. Agriculture and Human Values, 31, 425-437.

ILO. (2013). 'Bangladesh Government, employers and workers organizations sign integrated national action plan on fire safety and structural integrity in the garment sector', press release. Retrieved July 25, 2013, from https://www.ilo.org/ dhaka/Informationresources/Publicinformation/Pressreleases/ WCMS_218230/lang-en/index.htm.

ISPO (2014). Welcome. Retrieved March 17, 2014, from http://ispoorg.or.id/index.php?lang=en.

Köhne, T. (2014). Multi-stakeholder initiative governance as assemblage: Roundtable on Sustainable Palm Oil as a political resource in land conflicts related to oil palm plantations. Agriculture and Human Values, 31, 469-480.

Laasonen, S., Fougère, M., \& Kourula, A. (2012). Dominant articulations in academic business and society discourse on NGObusiness relations: A critical assessment. Journal of Business Ethics, 109, 521-545.

Laclau, E., \& Mouffe, C. (1985). Hegemony and socialist strategy: Towards a radical democratic politics. London: Verso.

Levy, D., \& Kaplan, R. (2008). CSR and theories of global governance: Strategic contestation in global issue arenas. The Oxford handbook of CSR (pp. 432-451).

Levy, D., Reinecke, J., \& Manning, S. (2016). The political dynamics of sustainable coffee: Contested value regimes and the transformation of sustainability. Journal of Management Studies, 53(3), 364-401.

Levy, D. L., Szejnwald Brown, H., \& de Jong, M. (2010). The contested politics of corporate governance: The case of the global reporting initiative. Business \& Society, 49(1), 88-115.

Mäkinen, J., \& Kourula, A. (2012). Pluralism in political corporate social responsibility. Business Ethics Quarterly, 22(4), 649-678.

Mayer, F., \& Gereffi, G. (2010). Regulation and economic globalization: Prospects and limits of private governance. Business and Politics, 12(3), 1-25.

Mena, S., \& Palazzo, G. (2012). Input and output legitimacy of multistakeholder initiatives. Business Ethics Quarterly, 22(3), 527-556.

Moog, S., Spicer, A., \& Böhm, S. (2015). The politics of multi-stakeholder initiatives: The crisis of the forest stewardship council. Journal of Business Ethics, 128, 469-493. 
Mouffe, C. (1999). Deliberative democracy or agonistic pluralism. Social Research, 66(3), 745-758.

Mouffe, C. (2000). The democratic paradox. London: Verso.

Mouffe, C. (2005[1993]). The return of the political. London and New York: Verso.

Mouffe, C. (2005b). On the political. London: Routledge.

Mouffe, C. (2013). Agonistics: Thinking the world politically. London: Verso.

Mouffe, C. (2015). An agonistic approach to cultural diversity. In Keynote speech at the Cultural Diversity in Music Education international conference, Musiikkitalo, Helsinki, June 11, 2015.

Ozkazanc-Pan, B. (2018). CSR as gendered neocoloniality in the Global South. Journal of Business Ethics. https://doi.org/10.1007/ s10551-018-3798-1.

Palazzo, G., \& Scherer, A. G. (2006). Corporate legitimacy as deliberation: A communicative framework. Journal of Business Ethics, 66(1), 71-88.

Public Eye. (2011). Neste oil and AngloGold in the Public Eye Pillory in Davos. Retrieved December 22, 2019, from https://www.publi ceye.ch/en/media-corner/press-releases/detail/neste-oil-and-anglo gold-in-the-public-eye-pillory-in-davos.

RAN. (2013). Palm oil producers, NGOs launch responsible palm oil initiative at RSPO AGM. Retrieved March 17, 2016, http://www. ran.org/palm-oil-producers-ngos-launch-responsible-palm-oilinitiative-rspo-agm.

Rancière, J. (2007). On the shores of politics. London: Verso.

Raymond, M., \& DeNardis, L. (2015). Multistakeholderism: Anatomy of an inchoate global institution. International Theory, 7(3), $572-616$.

RSPO. (2013). ISPO and RSPO enter into strategic co-operation. Retrieved March 15, 2014, from http://www.rspo.org/news_detai ls.php?nid=195.

RSPO. (2014a). Stakeholder categories. Retrieved March 17, 2014, from http://www.rspo.org/en/stakeholder_categories.

RSPO. (2014b). Vision and mission. Retrieved March 17, 2014, from http://www.rspo.org/en/vision_and_mission.

RSPO. (2015). Palm oil and deforestation: The solution is sourcing $100 \%$ certified sustainable palm oil. Retrieved March 3, 2016, from http://www.rspo.org/news-and-events/news/palm-oil-anddeforestation-the-solution-is-sourcing-100-certified-sustainabl e-palm-oil.

RSPO. (2016a). Transforming the market to make sustainable palm oil the norm (RSPO Who We Are infographic). Retrieved March 2, 2016, from http://www.rspo.org/publications/download/495b0 bc0b3fcb36.

RSPO. (2016b). Board of governors. Retrieved March 2, 2016, from http://www.rspo.org/about/who-we-are/board-of-governors.

Sawit Watch and ILRF. (2013). Empty assurances. Retrieved December 22, 2019, from https://laborrights.org/sites/default/files/publicatio ns-and-resources/Empty\%20Assurances.pdf.

Scherer, A. G., \& Palazzo, G. (2007). Toward a political conception of corporate responsibility: Business and society seen from a habermasian perspective. Academy of Management Review, 32(4), 1096-1120.

Scherer, A. G., \& Palazzo, G. (2011). The new political role of business in a globalized world: A review of a new perspective on CSR and its implications for the firm, governance, and democracy. Journal of Management Studies, 48(4), 899-931.

Scherer, A. G., Palazzo, G., \& Matten, D. (2014). The business firm as a political actor: A new theory of the firm for a globalized world. Business \& Society, 53(2), 143-156.

Scherer, A. G., Rasche, A., Palazzo, G., \& Spicer, A. (2016). Managing for political corporate social responsibility: New challenges and directions for PCSR 2.0. Journal of Management Studies, 53(3), 273-298.

Schouten, G., Leroy, P., \& Glasbergen, P. (2012). On the deliberative capacity of private multi-stakeholder governance: The roundtables on responsible soy and sustainable palm oil. Ecological Economics, 83, 42-50.

Schrempf-Stirling, J. (2018). State power: Rethinking the role of the state in political corporate social responsibility. Journal of Business Ethics, 150(1), 1-14.

Seitanidi, M. M. (2010). The politics of partnerships: A critical examination of nonprofit-business partnerships. Berlin: Springer.

Shamir, R. (2008). The age of responsibilization: On market-embedded morality. Economy and Society, 37(1), 1-19.

Shamir, R. (2011). Socially responsible private regulation: World culture or world capitalism? Law \& Society Review, 45(2), 313-336.

Swyngedouw, E. (2005). Governance innovation and the citizen: The Janus face of governance-beyond-the-state. Urban Studies, 42(11), 1991-2006.

Swyngedouw, E. (2011). Interrogating post-democratization: Reclaiming egalitarian political spaces. Political Geography, 30(7), $370-380$.

Taufik, K. (2016). Unilever palm oil supplier must suspend all plantation expansion to save reputation. The Guardian, April 92016. Retrieved June 22, 2016, from http://www.theguardian.com/susta inable-business/2016/apr/09/ioi-malaysian-palm-oil-companyunilever-mars-kellogg-rspo-deforestation.

The Daily Star. (2018). Tofail blasts Accord. Retrieved November 13, 2018, from https://www.thedailystar.net/business/news/tofail-blast s-accord-1659820.

Torfing, J. (1999). New theories of discourse: Laclau, Mouffe and Žižek. Oxford: Blackwell.

United Nations. (2015). Multi-stakeholder partnerships \& voluntary commitments. Retrieved June 1, 2018, from https://sustainabl edevelopment.un.org/sdinaction.

von Geibler, J. (2013). Market-based governance for sustainability in value chains: Conditions for successful standard setting in the palm oil sector. Journal of Cleaner Production, 56, 39-53.

Walmart. (2013). 'Walmart statement on IndustriALL Bangladesh factory labor proposal', press release. Retrieved May 14, 2013, from https://news.walmart.com/news-archive/2013/05/14/walmart-state ment-on-industriall-bangladesh-factory-labor-proposal.

Whelan, G. (2012). The political perspective of corporate social responsibility: A critical research agenda. Business Ethics Quarterly, 22(4), 709-737.

Whelan, G. (2013). Corporate constructed and dissent enabling public spheres: Differentiating dissensual from consensual corporate social responsibility. Journal of Business Ethics, 115(4), 755-769.

Widjaya, A. P. (2013). The politics of palm oil expansion and tropical deforestation in Indonesia. Helsinki University Social Forum Dialogues series (seminar), November 292013.

Yardley, J. (2013). Garment trade wields power in Bangladesh. The New York Times, July 13 2013. Retrieved August 21, 2019, from https://www.nytimes.com/2013/07/25/world/asia/garment-trade -wields-power-in-bangladesh.html.

Publisher's Note Springer Nature remains neutral with regard to jurisdictional claims in published maps and institutional affiliations. 